\title{
Crop diversification and household food security status: evidence from rural Benin
}

(2) CrossMark

\author{
Gilbert Onionkiton Adjimoti ${ }^{*}$ and George Tsey-Mensah Kwadzo
}

\begin{abstract}
Background: The government of Benin has initiated since 2006 many policies to promote crop diversification. The aim was to help rural household to be more resilient to food insecurity. The objective of this research is to determine how crop diversification has affected the food security status of the rural household.

Methodology: Primary data from 420 rural households were collected in the Collines Region in Benin. We use principal component analysis (PCA) to construct a multidimensional food security indices and a Simpson diversity index has been used to measure the degree of crop diversification. A linear regression model was used to determine the effect of crop diversification on household food security status.

Results: We found that crop diversification has a positive effect on household food security status. The diversity of crops grown through dietary diversity can improve household food security. In rural remote areas where household access to food depends largely on it production, crop diversification provides farmers with the different crops that they cannot access either because of the cost or because of the poor infrastructure constraints (physical access). Beyond, the results also show that some other factors are also affecting the household food security status such as access to extension services and storage facilities.
\end{abstract}

Keywords: Benin, Crop diversification, Food security, PCA, Policy

\section{Background}

Achieving the second objective of the sustainable development goals which is zero hunger requires finding ways to increase the income and assets of rural people living in developing countries. Yet, reducing food and nutrition insecurity in the developing countries continues to be a major public policy challenge. Food insecurity has become a global challenge for policy makers particularly in Sub-Saharan Africa where the rate of population growth far exceeds the quantity and quality of food needed to feed the population. Most of poor population like in Benin to some degree depend on agriculture and especially small-scale farming systems as the primary source of their livelihoods. Agriculture is central to rural development, food insecurity reduction and rural

\footnotetext{
*Correspondence: adjilbert@yahoo.fr

Department of Agricultural Economics and Agribusiness, University of Ghana, P.O. Box 65, Legon, Accra, Ghana

All the authors have participated in the different committee meeting that validated each phase of the study.
}

poverty alleviation [29]. Smallholder farmers are fundamental in achieving food and nutrition security and sustainable rural development. According to Antonaci et al. [3], smallholder farmers produce $80 \%$ of the food in SubSaharan Africa and are the largest providers of work for the local labor force in many developing countries. This is not only because poverty is still concentrated in rural areas, but the agricultural sector also typically accounts for a large share of national income and employment. In Benin for instant, the sector employs $70 \%$ of the labor force and contributes about 35\% of the GDP [41]. According to Cervantes-Godoy and Dewbre [8], people in developing countries who depend on agriculture for their living are typically much poorer than people who work in other sectors of the economy and that they represent a significant share, often the majority, of the total number of the poor people in the countries where they live. Van Wijk [42] recognized that policy can play a key role in defining the different role of agriculture in food security and sustainable development. 
Although agriculture-led growth played an important role in reducing food and nutrition insecurity and transforming the economies of many Asian and Latin American countries, most countries in Africa have not yet met these criteria for a successful agricultural revolution. Risk and uncertainty are the major characteristics of agricultural production in developing countries [1, 17]. Smallholder farmers are facing a lot of challenges in many areas including low soil fertility, climate change, water shortage, dysfunctional input-output market, weak extension services and poor policy [36]. As a result, many rural households are facing decreasing agricultural productivity, food and nutrition insecurity, and income variability which affect negatively their livelihoods. Among these issues, the food and nutrition insecurity and income variability are the main component of smallholder farmers' livelihoods. Crop diversification can be used as a tool to increase farm income, generate employment, alleviate poverty, conserve soil and water resources. It is therefore reckoned as an important strategy to overcome many of the emergencies faced by agricultural household in developing countries [20]. In India, Mandal and Bezbaruah [23] found that as flood risk-coping mechanism, crop diversification has positive impact on farmers income. In Guatemala, Von Braun [39] showed that diversification into export vegetable production has increased rural employment by $45 \%$. Similarly, Ali and Abedullah [2] reported that diversification toward high-value commodities has generated substantial employment in seed and seedling production. Recently, Birthal et al. [5] acknowledged that households diversifying toward high-value crops are less likely to be poor.

In rural Benin, household access to food largely depends on what the household grows, either because they consume what they grow, or they purchase food with the income earned from what they grow. Also, due to very high transportation costs, poor infrastructure and to the remoteness of the rural area in Benin, many rural households are forced to rely on their agricultural production or on the locally produced crops to satisfy their nutritional needs. On that condition, crop diversification can be an important mean of reducing food insecurity in rural Benin.

Still, reducing rural food insecurity is one of the biggest challenges of public policies in Benin. According to INSAE [18], about $25 \%$ of rural household in Benin are highly food insecure (cannot ensure the basic food needs without help) and about $45 \%$ are at the risk of food insecurity and the country remains one of the poorest in the world with an incidence of poverty estimated at $46 \%$ in rural areas.

Although the researches on the crop diversification are oft remarked especially in Asia, few attempts have been made to link it to the food security in Africa. Pellegrini and Tasciotti [27] recognized that due to very high transportation costs and to the remoteness of the villages they live in, some rural dwellers are forced to rely on their agricultural production and the locally produced crops to satisfy their nutritional needs.

Herforth [16] examined the relationship between farm diversity and dietary diversity among households in central Kenya and northern Tanzania. In both Kenya and Tanzania, the number of crops grown by a household was positively associated with the dietary variety of the household (i.e., the number of unique foods in the diet) and in Tanzania, crop diversity was associated with the diversity of food groups in household and individual child diets. In both countries, crop diversity was also positively associated with the diversity of home-produced fruits and vegetables consumed. In the rural highlands of Ecuador, on-farm species diversity and family-level dietary diversity were also positively correlated [26]. Families with low agrobiodiverse farms in this setting consumed more off-farm food items. In western Mali, the number of crops cultivated by a household was positively associated with adult nutrient adequacy [38].

Recently, Jones et al. [19] found that the production diversity of farms in Malawi was consistently and positively associated with the diversity of household diets. Farm diversity demonstrated a consistent positive association with household dietary diversity independent of differences in household wealth and social standing. This relationship was significantly greater in wealthier households as well as in households headed by women. Farm diversity was especially strongly associated with consumption of legumes, vegetables and fruits.

Although there is no a single approach to measure the household food security status, accurate measurement indicator is necessary to target resources toward those most in need or at risk of sliding into hunger. Accurate measurement of household food security is also essential for effective research and well-targeted policies and programs. According to Carletto et al. [7], a wide range of indicators are used for food security analysis and the best way is to define clearly the intended scope. The definition of food security is generally understood as a situation whereby "all people, at all times, have physical, social and economic access to sufficient, safe and nutritious food to meet their dietary needs and food preferences for an active and healthy life" [11]. There are three important components in this definition: food quantity available in the household, food quality as capture by diet diversity and stability of adequate food supplies.

Most studies try to conceptualize the food security into different way. Two conceptual components have been widely used. The first one is to analyze food security 
through the set "quantity, quality and stability". The second approach is to follow the conventional components embedded in the definition of food security which are availability, accessibility, utilization and the stability: (1) the availability of food in terms of its physical presence in a given country/household; (2) the access to food as reflected by people's ability to obtain food from own stock/home production, or through market purchases, gifts or borrowing; and (3) the utilization of food, in terms of the ability to derive full biological benefits from food, based on food safety and nutritional/socio-cultural value [37].

Food availability is a combination of domestic food production and food stocks, commercial food imports and food aid. The term 'availability' is usually used in reference to food supplies at the regional or national level [30]. At the household level, the indicators commonly used are household food production and social safety nets (food aid). Some researchers Demeke and Zeller [10] also suggested to use the tropical livestock unit as a determinant of the availability. In the case of Collines Region, the livestock is not developed and its contribution to the household income remains very low.

Accessibility is the ability of the household to get food by having adequate resources, or entitlements, to acquire a sufficient quantity of food, and while consumers' purchasing power in the form of real incomes and food prices is important, entitlements are not necessarily monetary. One of the key determinants of the accessibility is the household income. The income here will be measured with the agricultural production income and the non-farm income. Maxwell et al. [24] add the nonagricultural assets. In the context of Collines Region, household may rely on some physical assets when the food shock occurred.

Utilization is related to health and reflects concerns about whether individuals make good use of the food to which they have access [4]. The variety of food group consumed and the calorie intake are the most indicated determinants of the utilization.

\section{Methodology}

\section{Location of the study and sampling techniques}

The data used for this study are exclusively from primary source and were collected from five municipalities located in the Collines Region in Benin. A questionnaire was designed and administrated at the household level to the head of household through face-to-face interview.

\section{Location of the study}

Benin is a coastal country located in West Africa (see Fig. 2). It is divided into twelve Regions including the Region of Collines. Located in the center of Benin, Collines
Region covers an area of $13,931 \mathrm{~km}^{2}$ which represents $12 \%$ of the total area of Benin. According to the last general census of the population in 2013, it has 716,558 inhabitants, representing $7.2 \%$ of the total population of Benin. The region is divided into six municipalities: Bante, Dassa-Zoume, Glazoue, Ouessè, Savalou and Save. The economic activities of the area are primarily based on agriculture (71\%). Regarding agriculture, the region provides an important part of the national supply as evidenced by production statistic. The region is the largest producer of roots and tubers and vegetables in Benin. In regard to cereals, the region usually ranks second or third position. This is an ideal area for the analysis of livelihood strategies of people given the diversity of crops grown. Yet, this is one of the poorest regions of Benin, with an incidence of poverty estimated at $46 \%$ in 2011 [18]. The food situation in the region is also critical despite the amount of agricultural production that comes from this region (Fig. 1).

\section{Sampling techniques}

The study used the multistage sampling procedure where it started with a purposive selection of the Collines Region. We chose the region because the crops diversification level is very high and households are engaged in growing on average more than three crops. At the same time, the region is one of the most food insecure in the country. There are six municipalities within the region. Based on the importance of agricultural activities in the municipalities, five municipalities out of six served as the study area: Bante, Dassa-Zoume, Glazoue, Ouessè, Savalou. Firstly we compute a sample size using [9] approach:

$$
n=z^{2} \times p(1-p) / m^{2}
$$

$n$ required sample size, $z$ confidence level, $p$ estimated prevalence of farm attribute in the area, $m$ margin of error.

In our specific case, in order to minimize the error, we used the confidence level of $95 \%$ with the standard value of 1.96; the margin of error $(m)$ is $5 \%$. Our general population is all the crop farm households in the Collines Region, and they represent $65 \%$ of the total household in the Region [18]. Therefore, $p=0.65$.

$$
n=1.96^{2} * 0.65(1-0.65) / 0.05^{2}=350
$$

We increased the sample size by $20 \%$ to account for contingencies such as non-response or recording error.

$$
\begin{aligned}
& N *=350 * 1.20 \\
& N *=420
\end{aligned}
$$

The next stage was the distribution of the 524 respondents among the five municipalities according to the percentage of farm household in the municipalities. The distribution is shown in Table 1. 


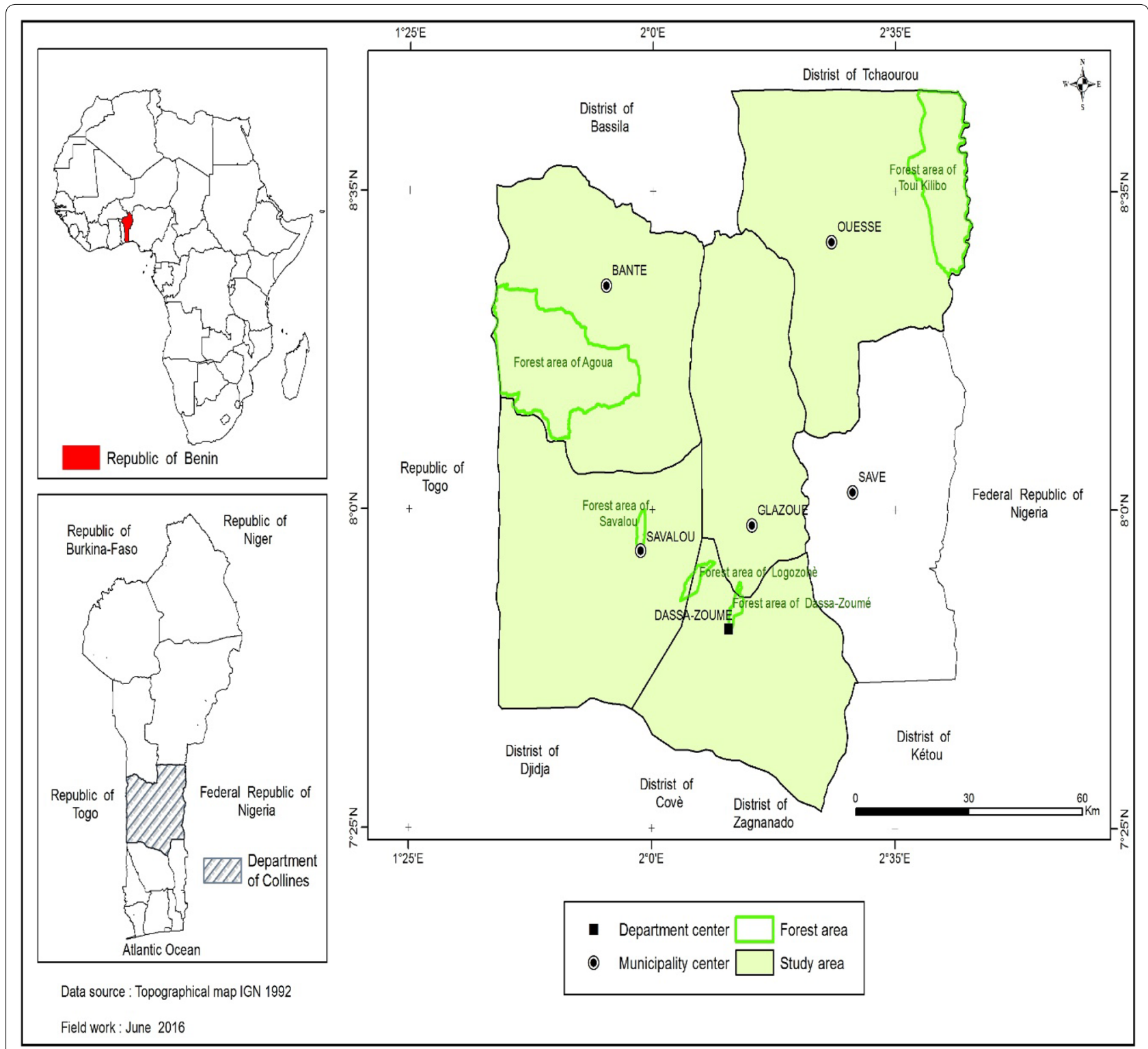

Fig. 1 Location of the study

Each municipality is divided into districts, and each district is divided in villages/communities (Municipalities-Districts-Villages/Communities-Households). First, we randomly selected $50 \%$ of the districts in each municipality and where the number of district is odd, we chose the maximum (for example, if the number of the district is 09 , we retained 05). Within the districts, we purposively chose one village/community proportionate to the number of the farm household in each village (they are also the main agricultural production villages). The share of the farm household in each municipality and district was collected from the National Statistical Institute of Benin. In each village, we randomly selected $5 \%$ of the total farm households based on the information provided by the agricultural extension officers and the farmers-based organizations. The farm households that were enumerated were randomly selected from the total agricultural household list of the villages.

\section{The food security index}

As a multidimensional concept, food security study requires the use of multivariate descriptive statistic and a good indicator has to take all the aspects into consideration. To be able to do this, it may be useful to construct a multidimensional index that incorporates the most important indicators from each dimension of food security. 
Table 1 Sampling Distribution of household respondents

\begin{tabular}{|c|c|c|c|c|c|c|}
\hline Municipalities & Bante & Dassa & Glazoue & Ouesse & Savalou & Total \\
\hline Population ${ }^{a}$ & 106,945 & 112,118 & 123,542 & 141,760 & 144,814 & 629,179 \\
\hline Total household & 13,368 & 16,016 & 19,006 & 20,251 & 18,101 & 86,742 \\
\hline $\begin{array}{l}\text { Crops production } \\
\text { households }^{\mathrm{a}}\end{array}$ & 9438 & 10,132 & 11,575 & 14,062 & 11,175 & 56,382 \\
\hline Percentage & 16.74 & 17.97 & 20.53 & 24.94 & 19.82 & 100 \\
\hline Sample size & 70 & 75 & 86 & 105 & 84 & 420 \\
\hline
\end{tabular}

a Estimation from National Statistical Institute (2014)

The factorial methods have been developed for this purpose and include factor analysis, the principal component analysis and correspondence analysis. However, the major difficulty of the analysis is based on the interpretation of results obtained. Factor analysis is, according to Bry [6], a geometric principle allowing automatic conversion of a large table of data in synthetic images from which will emerge the main structures. By extracting the maximum information, PCA aims to study the linear connections between variables and to identify homogeneous groups of individuals from the correlation matrix or covariance.

The principal component analysis (PCA), therefore, gives a description of the statistical units and observed variables based on the study of the correlation coefficients. It is not based on a probabilistic model and may therefore affect a whole population or a sample. It is not either a regression since we are not explain a variable from other, but rather a summary of the information contained in these variables. Moreover, PCA highlights the similarities and contrasts between the analyzed units. The originally correlated variables are compressed and processed independent variables called principal components or axes. They allow to carry out a geometric representation that best explained the variability in the data. The PCA provides thus a system of orthonormal axes retaining all the distances between the variables, hence the delineation of groups of individuals with similar characteristics. PCA is used for heterogeneous data, while factor correspondence analysis (FCA) is used for contingency tables, but also allows analyzes of qualitative data. The FCA is rather recommended for large tables identical data (expressed in the same unit).

The aim of the PCA is to be able to group all the food security aspect into one indicator and facilitate the interpretation.

\section{Construction of the food security index}

We use PCA to construct a composite food security index by incorporating several indicators (food accessibility, food affordability, food utilization and food stability) that are supposed to capture the different dimensions of food security. The PCA extracts the linear combination of these variables which give the maximum variance and transform them into one index [43]. The first principal component is the linear combination capturing the greatest variation among the set of variables. This was converted into factor scores, which served as weights for the creation of an index for each household. In other words, from an initial set of $n$ correlated variables $\left(X_{1}, X_{2} \ldots\right.$ $\left.X_{n}\right)$, PCA creates $m$ uncorrelated principal components where each is a linear weighted combination of the initial variables as follows:

$$
P C_{m}=a_{m 1} X_{1}+a_{m 2} X_{2}+a_{m 3} X_{3}+\cdots+a_{m n} X_{n}
$$

where $a_{m n}$ represents the weight for the $m$ th principal component and the $n$th variable. The components are ordered so that the first component explains the largest amount of variance in the data subject to the constraint that the sum of the squared weights $\left(a_{m}^{2}+a_{m}^{2} \frac{1}{2} a_{m}^{2} \frac{1}{3}\right.$. .. $\left.+a_{n n}^{2}\right)_{n}$ is equal to one. Each subsequent component explains additional but less proportion of variation of the variables. The higher the degree of correlation among the original variables, the fewer components required to capture common information [40]. Once the first component was identified, we derived the food security index for each household as follows:

$$
\mathrm{FSI}_{j}=\sum F_{i}\left[\frac{X_{i j}-X_{i}}{S_{i}}\right]
$$

FSI $_{j}$ is the food security index for the household $j$. $F_{i}$ is the weight for the $i$ th variable. $X_{i j}$ is the $j$ th household's value for the $i$ th variable. $X_{i}$ and $S_{i}$ are the mean and standard deviations of the $i$ th variable for overall households.

The results of the PCA were generated through SPSS program. The identification and selection of indicator variable were based on the food security literature as well as the four components of food security.

\section{Choice of the variables}

Availability Food availability refers to the physical supply of food for the household. In this study, the availability was measured by the food crop land size, the cereal land 
size, the cereal production and the cereal production per capita. They all helped to estimate how much food was available in the household. Although cereal land size was already included into food crop land size, we separately considered cereal because of their contribution to the household consumption status.

Accessibility The food access is related to the household ability to acquire food; it depends on the range of food choice open to household given their income, market price and market accessibility. Two indicators have been retained here to measure the food access: income per capita and distance to market. The income per capita was calculated using the total gross household income divided by the household size.

Utilization Utilization is related to health and reflects concerns about whether individuals make good use of the food to which they have access [4]. We use the food consumption score as the measure of utilization for the study because it is a composite score based on dietary diversity and food frequency.

Stability The stability dimension deals with the fact that people's food security situation may change over the time. Therefore, the number of months without food stock was used to measure the stability.

\section{Measures of crop diversification}

Crop diversification could be defined as the introduction or development of additional crops to the existing farming system (Makate et al. 2016). The main aspect and the most understood concept of crop diversification is the addition of more crops to the existing cropping system, which could be referred to as horizontal diversification [20]. For example, substitute or add more crops into an existing farming system can be understood as crop diversification. However, this type of crop diversification means the broadening of the base of the system, simply by adding more crops to the existing cropping system utilizing techniques such as multiple cropping techniques coupled with other efficient management practices.

Other words are also used to express crop diversification. For example, we have crop substitution and adjustment which are also related to the primary concept of crops diversification, but they are just a way of optimizing profit and manage land [12]. Diversification at farm level will involve growing of more than one crop in order to achieve self-sufficiency, which is quite different at the national level. At national level, crop diversification will require additional resources and management of a specific or group of crops sold freshly or value added to increase profits [13].

There are several ways to measure crops diversification, and the most important include Herfindahl Index, Simpson Diversity Index, Ogive Index, Margalef Index, Shannon
Index, Berger-Parker Index and Entropy Index. Another common method for measuring the crop diversification is to count the number of crop grown by farmer.

Herfindahl index (HI) The Herfindahl index is a concentration index which is often used to determine the concentration of industry. It decreases gradually as the level of diversification increases. It takes the value 1 when there is total concentration and tends to zero as the level of diversification increased [33]. In the context of crops diversification, Herfindahl index is used to study the extent of crops diversification. The formula is given as below.

$$
\mathrm{HI}=\sum_{i=1}^{N} P_{i}
$$

where $N$ is the total number of crops cultivated and $P_{i}$ accounts for the land share of the $i$ th crop in total cropped area.

Simpson diversity index (SDI) SDI was introduced in 1949 to assess the degree of concentration when individuals are grouping into type. The same index is often used to measure the extent of diversification.

The square root of the index has already been introduced by Hirschman. As a result, the same measure is usually known as the SDI in ecology and as the HI or the HHI (Herfindahl-Hirschman Index) in economics. $\mathrm{SDI}=1-\sum_{1}^{n} P_{i}^{2}$.

$P_{i}$ is the proportionate area of the $i$ th crop in the gross cropped area; $n$ is the total number of crops grow by the household.

Ogive index (OI) Ogive Index is used to evaluate countries specialization and concentration. It has been also used to estimate the diversification at the farm level. The description of the index is given in the following formula.

$$
\mathrm{OI}=\frac{\sum_{i=1}^{n}\left[P_{i}-\left(\frac{1}{N}\right)\right]^{2}}{\left(\frac{1}{N}\right)}
$$

$\mathrm{N}$ represents the number of crops; $P_{i}$ is the proportionate area of the ith crop in the gross cropped area.

Bhatia's method Bhatia's Index (BI) is inversely proportional to the degree of crops diversification. It means that as the index increased, the degree of crops diversification will reduce and vice versa. After identifying those crops 
which have more than $10 \%$ of cropped areas, we compute the formula below.

$$
\mathrm{BI}=\frac{\text { Percentage of total cropped area under ' } n \text { ' crops }}{\text { Number of ' } n \text { ' crops }}
$$

Entropy measures for crop diversification Entropy Index evaluates the shares of farm activity in logarithm term with the inverse measure of the shares. This index has been widely used in the area of crops diversification [31]. The Entropy Index of Diversification (DIE) is computed using the formula DIE $=\Sigma\left[P^{2} i t \times \operatorname{In}(1 /\right.$ Pit $\left.)\right]$.

With $P_{i}$ the proportion of cultivated land for the $i$ th crop. DIE is supposed to increase as the level of diversification increases and vice versa. The difference between the first level of diversification and the perfect diversification for a given number of crops is measured by the Berry's index as DIB/[1-(1/n)], while for Entropy Index as $\mathrm{DIE} / \operatorname{In}(n)$ more the Entropy or Berry's measures value expected is the result or otherwise [33].

All these indices are computed on the basis of proportion of gross cropped area under different crops cultivated in a particular geographical area. Simpson Index is usually known as Simpson Diversity Index in ecology and as the HHI (Herfindahl-Hirschman Index) in economics, and we used it as diversification index for the present study. One of the advantage of using Simpson Diversity Index in the present study is that it does not required farmers to produce all type of crops.

\section{Effect of crop diversification on household food security}

The constructed food security index was included as a continuous dependent variable in a regression model [10].

$$
Y i=\rho Z i+\varphi D i+\varepsilon i
$$

where $Y i$ is the household food security index, $D i$ is the Simpson Diversity Index, $Z i$ is the vector of others explanatory variable for household $i$, and $\varepsilon i$ is the error term.

Gender of the household head It is generally shown that female-headed household in the context of developing countries is more food insecure than maleheaded households [22]. Recently, Magaña-lemus et al. [21] also showed that due to the lack of resources, female-headed households in Mexico are more likely to be food insecure than male-headed households.

Age of household head Age of the household head can significantly affect their food security status. According to Perz [28], elder household (more than 45 years) heads have more experience in allocating their resources to achieve the household need. On the contrary, Magaña-lemus et al. [21] show that younger household heads are more dynamic in searching for more opportunities and so their households are more likely to be food secure.

Education Education as the main indicator of human capital can improve the opportunities for the household head. Households with more education tend to be more food secure [21]. Lower education level negatively affects the opportunities of getting non-farm employments (Table 2).

Membership of farmers association The new agricultural policy in Benin considers FBOs as a key bridge through which reliable information on agricultural technologies will flow. Farmers associations are also a kind of social capital that can help to overcome some of the food challenges. Being a member of an association may provide reliable information and opportunities.

Access to fertilizer and seed Access to inputs is key components of agricultural production and therefore can enhance the productivity. It is expected that fertilizer use will improve household food security status. All things equal, [32] shows that fertilizer plays an important and critical role in improving yield and therefore food security.

Number of extension visits The number of extension visit as a knowledge will enhance production techniques and productivity. It is expected that the number of extension visit will be positively related to the household food security status.

Location As a dummy variable, the location as a determinant of diversity will capture the difference in culture and environmental conditions in which farm household's work and how this is related to food security.

Total land size the amount of land a household owns plays an important role in the crop production quantity. The more land cultivated by the household, the better the household will be in terms of food security.

Access to formal credit In this study, access to credit is defined as having request for and getting the full amount of credit. Those who get partial amount or who did not request because of lack of collateral, absence of credit institutions or any other reason or did not get any amount at all are considered as not having access to credit. Credit access may facilitate the household capacity to acquire more inputs and food for the household.

Tropical livestock unit As asset accumulation, tropical livestock unit plays an important role in the household especially when crop production fails to provide sufficient food for the household. Households may sell a part of their livestock to buy food.

Storage facilities Storage facilities played a key role in storing and conserving food crops and prevent them 
Table 2 Description of Independent variables

\begin{tabular}{|c|c|c|}
\hline Variable & Description & Measurement \\
\hline Diversity & Simpson Diversity Index (D) & Continuous \\
\hline Gender & Gender of the household head (SEX) & 1 for Male and 0 for Female \\
\hline Age & Age of the household head (AGE) & Continuous \\
\hline Family size & Number of person in the household (FSIZE) & Continuous \\
\hline Education & Whether household head attended school (EDUC) & $\begin{array}{l}1 \text { for none and } 0 \text { else } \\
1 \text { for primary and } 0 \text { else } \\
1 \text { for secondary and } 0 \text { else }\end{array}$ \\
\hline Credit & Access to credit (CREDIT) & 1 for access and 0 else \\
\hline Association & Membership of farmers association (ASSOC) & 1 if yes and 0 else \\
\hline Location & Location of the household head Dummy variable & $\begin{array}{l}1 \text { if Bante and } 0 \text { else } \\
1 \text { if Dassa and } 0 \text { else } \\
1 \text { if Glazoue and } 0 \text { else } \\
1 \text { if Ouesse and } 0 \text { else } \\
1 \text { if Savalou and } 0 \text { else }\end{array}$ \\
\hline Fertilizer & Access to fertilizer (FERTI) & 1 if yes and 0 else \\
\hline Seed & Access to improved seed (SEED) & 1 if yes and 0 else \\
\hline Extension & Number of extension visit per year (EXTEN) & Continuous \\
\hline Land size & Total land size (LSIZE) & Continuous (in hectares) \\
\hline Storage & Access to storage facilities (STOR) & 1 if yes and 0 else \\
\hline Livestock & Tropical livestock Unit (TLU) & Continuous \\
\hline
\end{tabular}

Table 3 Descriptive statistics

\begin{tabular}{llll}
\hline & Mean & SD & Analysis $\boldsymbol{N}$ \\
\hline Food crop land & 4.088 & 1.854 & 420 \\
Cereal land & 1.815 & 1.075 & 420 \\
Cereal production & 3212.57 & 3425.905 & 420 \\
Cereal/capita & 196.899 & 269.273 & 420 \\
FCS & 41.181 & 10.603 & 420 \\
Income/capita & $82,847.684$ & $74,902.324$ & 420 \\
Food stock & 1.94 & 1.542 & 420 \\
Market & 2.593 & 1.226 & 420 \\
\hline
\end{tabular}

from being damaged by pest attack. It is measured as a dummy variable.

\section{Result and discussion}

\section{Result of the principal component analysis}

Table 3 presents the descriptive statistics of the variable loaded for the PCA. There is a disparity for some of the variables such as income per capita, cereal production and cereal production per capita as evidenced by their high their standard deviation.

The suitability of the data for the PCA was checked using the Bartlett's test of sphericity and the KMO measure of sampling adequacy (Table 4). The result shows that the KMO is greater than 0.6 and the Bartlett's test is also significant.
Table 4 Bartlett's test of sphericity and the KMO test

\begin{tabular}{ll}
\hline KMO and Bartlett's test & \\
\hline Kaiser-Meyer-Olkin measure of sampling adequacy & 0.615 \\
Bartlett's test of sphericity & \\
Approx. Chi Square & 2116.405 \\
$d f$ & 28 \\
Sig. & 0.000 \\
\hline
\end{tabular}

Table 5 presents the total variance explained in the table to determine how many components to extract considering only those components with eigenvalues of 1 or more. Looking at Table 5, only the first 3 components have an eigenvalues above 1; these three components explained up to $71 \%$ of the total variance within this set of data. The components matrix presented in Table 6 shows the contribution of each variable to the principal component which is the food security. The food security index was directly derived from the component matrix. After computation, Fig. 2 shows the distribution of the food security index. About $37.5 \%$ of the households were food insecure. According to [25] the calculated food security index can range from 0 (worst case) to 1 (best case) and can be classified into four thresholds:

$0<\mathrm{FSI}<0.341$ alarming food insecure.

$0.342<\mathrm{FSI}<0.435$ moderate food insecure.

$0.436<\mathrm{FSI}<0.558$ moderate food secure.

$0.559<\mathrm{FSI}<1$ highly food secure. 
Table 5 Total variance explained

\begin{tabular}{|c|c|c|c|c|c|c|c|c|c|}
\hline \multirow[t]{2}{*}{ Component } & \multicolumn{3}{|c|}{ Initial eigenvalues } & \multicolumn{3}{|c|}{ Extraction sums of squared loadings } & \multicolumn{3}{|c|}{ Rotation sums of squared loadings } \\
\hline & Total & $\%$ of variance & Cumulative \% & Total & $\%$ of variance & Cumulative \% & Total & $\%$ of variance & Cumulative \% \\
\hline \multicolumn{10}{|c|}{ Total variance explained } \\
\hline 1 & 2.711 & 33.893 & 33.893 & 2.711 & 33.893 & 33.893 & 2.710 & 33.873 & 33.873 \\
\hline 2 & 1.897 & 23.716 & 57.609 & 1.897 & 23.716 & 57.609 & 1.891 & 23.642 & 57.516 \\
\hline 3 & 1.078 & 13.479 & 71.088 & 1.078 & 13.479 & 71.088 & 1.086 & 13.572 & 71.088 \\
\hline 4 & 0.978 & 12.227 & 83.315 & & & & & & \\
\hline 5 & 0.827 & 10.331 & 93.646 & & & & & & \\
\hline 6 & 0.271 & 3.386 & 97.032 & & & & & & \\
\hline 7 & 0.136 & 1.703 & 98.735 & & & & & & \\
\hline 8 & 0.101 & 1.265 & 100.000 & & & & & & \\
\hline
\end{tabular}

Extraction method: principal component analysis

Table 6 Component matrix

\begin{tabular}{|c|c|c|c|}
\hline \multirow[t]{2}{*}{ Component matrix ${ }^{a}$} & \multicolumn{3}{|c|}{ Component } \\
\hline & 1 & 2 & 3 \\
\hline Income/cap & 0.897 & & \\
\hline Cereal product & 0.884 & & \\
\hline Cereal/cap & 0.857 & & \\
\hline Food cropland & & 0.961 & \\
\hline Cereal land & & 0.961 & \\
\hline Market & & & -0.806 \\
\hline Food stock & 0.421 & & 0.527 \\
\hline FCS & & & 0.350 \\
\hline
\end{tabular}

Extraction method: principal component analysis

a 3 components extracted

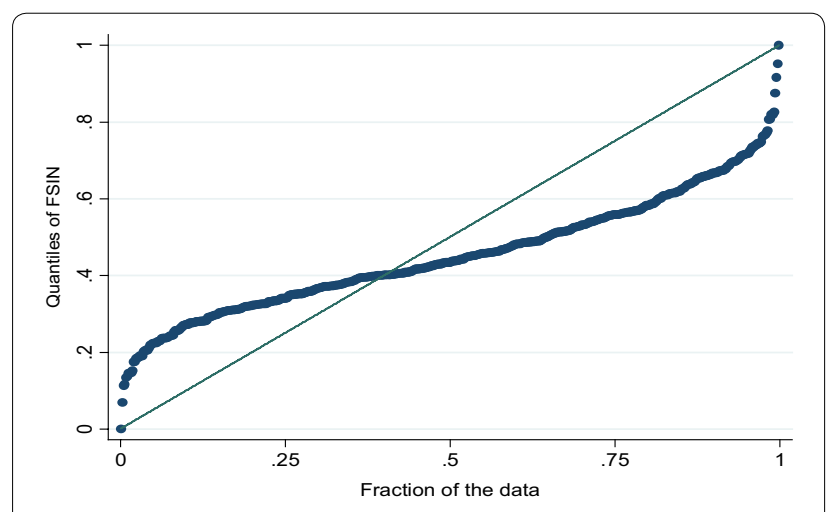

Fig. 2 Distribution of the food security index

\section{Estimation results}

Table 7 below presents the results of the effect of crop diversification on household food security. The results indicated that the crops diversification (represented by
Table 7 Estimation results Source: Data collected in 2015

\begin{tabular}{lll}
\hline Variables & Coefficients & P value \\
\hline Age & -0.001 & 0.226 \\
Sex & -0.035 & 0.123 \\
Education & & \\
$\quad$ Primary & 0.007 & 0.567 \\
Secondary & $0.119^{* * *}$ & 0.000 \\
FBOs & 0.059 & 0.200 \\
Extension Services & $0.067^{* * *}$ & 0.000 \\
Location & & \\
Glazoue & -0.015 & 0.455 \\
Dassa & -0.010 & 0.631 \\
Ouesse & -0.027 & 0.175 \\
Savalou & -0.030 & 0.139 \\
Credit & $0.035^{* *}$ & 0.023 \\
Simpson Diversity Index & $0.198^{* * *}$ & 0.000 \\
Seed & 0.019 & 0.185 \\
Fertilizer & 0.006 & 0.660 \\
Tropical livestock unit & $0.101^{* *}$ & 0.023 \\
Storage & $0.051^{* * *}$ & 0.000 \\
Land Size & 0.001 & 0.125 \\
Constant & 0.383 & 0.000 \\
Number of observation $=420$ & & \\
F(17, 504) =8.07 & & \\
Prob $>$ F=0.000 & & \\
R-squared =0.2139 & & \\
\hline
\end{tabular}

*Significant $10 \%$

**Significant $5 \%$

***Significant $1 \%$

Simpson diversity index) was significant with positive coefficient. Households growing many crops were more likely to be food secure especially those diversifying into cereals and root and tuber crops. If we assume there is a strong correlation between household dietary diversity 
and household food security status, we can state that this result are in line with that of Jones et al. [19] who found that more diverse production systems can also lead to more diverse household diets in Malawi. Regarding the remoteness and the poor quality of infrastructure in our study areas, most of the household food access depends on what the household produces mostly because their food diet is linked with their food crops production. Household may choose to diversify crops because of poor infrastructure [14], and this will help them to get the kind of food they need at the local level. Similar results were reported by Herforth [16] who found that in Kenya and Tanzania, the number of crop grown by household is associated with the dietary variety of the household.

The level of education also affected positively the household food security status, and we found that household head who reach secondary school were more likely to have their family food secure. Considering as social capital, education can provide additional opportunity for farmers in term of non-farm employment which may improve household food security status [13]. Also, educated household head are more likely to absorb technologies and new farm technics. Like education, access to extension services was also considered as knowledge acquisition and the result showed a significant and positive relationship between access to extension services and household food security status. This is because contact with extension services tends to enhance the chances of a household having access to better crop production techniques, improved inputs, as well as other production incentives that positively affect farm production and thus household food security.

The results further revealed that access to credit affects positively the household food security status meaning that household with credit access has more chance to be food secure than those without credit access. Access to credit gives the household the opportunity to invest in agricultural business or other nonfarm activities which may enhance the household food security profile. The result is in line with the finding of Gecho et al. [15]. According to Tekle and Berhanu [35], credit can also help households to smooth consumption especially during the food shortage period.

Tropical livestock unit also affects positively the household food security status. Livestock plays an important role in household livelihood strategies in the study area and is used mostly as assets accumulation by many households. Livestock contributes to food security status of households in different ways such as by providing cash income, nutrition, draft power, manure, etc. Also livestock serves as savings of assets and used to cope with food insecurity problems during food shortage. Access to storage facilities was also significant and positively associated with household food security status. Storage facilities contribute to reduce food losses and provide households with the opportunity to smooth hunger during lean season. Additionally, farmers are able to improve farm incomes by storing and selling their farm produces at premium prices when demand outstrips supply later in the food shortage period. According to Tefera et al. [34], storage is crucial to improve agricultural incomes and food security for smallholder farmers.

\section{Conclusion and policy recommendations}

Food insecurity in rural areas remains a key challenge to be addressed by policies in Benin. This paper investigates the potential effect of crops diversification on household's food security status. Considering the Simpson diversity index as diversification measurement and multidimensional food security index, the study comes out with the findings that crops diversification contributes to the household food security status. In rural remote Benin like the Collines Region, household's access and consumption of food depend mainly on their production and therefore the set of crops to be produced is an important determinant of household food security status. Additionally, many variables affect household's food security status such as: level of education, access to extension services, credit, storage and the tropical livestock unit. The crops diversification policy lunched in 2006 which aim was to help rural households to diversify their livelihood and reduce risk need to be strengthened in order to reduce food insecurity in the country.

Focus on food security ensures that the basic needs of the poorest and most vulnerable groups are not neglected in policy formulation and that requires taking into account all the food security components. Beyond the crops diversification policy, government has to design and implement livelihood diversification policy and design a clear food and nutrition policy document. There is a need to reinforce instruments designed to support crops diversification and strengthen agricultural support services in rural areas.

\section{Authors' contributions}

GA is a final year Ph.D. Candidate in Applied Agricultural Economics and Policy. This study is part of his Ph.D. thesis. GA has coordinated the field work for data collection and did the write up of the study under his supervisors. GK is the main Supervisor for this study. He coordinated and supervised the whole process of this research from the proposal to the mains findings. All authors have participated in the different committee meeting that validated each phase of the study. Both authors read and approved the final manuscript.

\section{Authors' information}

GA is a final year Ph.D. Candidate in Applied Agricultural Economics and Policy, University of Ghana. This study is part of his Ph.D. thesis. GA areas of study involve Food policy, social protection, gender and rural development. GK is a 
Senior Lecturer at the Department of Agricultural Economics and Agribusiness of the University of Ghana. His areas of specialization include Rural Finance, Project management, policy negotiation and agribusiness.

\section{Acknowledgements}

Not applicable.

\section{Competing interests}

The authors declare that they have no competing interests.

\section{Availability of data and materials}

The datasets used and/or analyzed during the current study available from the corresponding author on reasonable request.

\section{Consent for publication}

Not applicable.

Ethics approval and consent to participate

Not applicable.

\section{Funding}

Not applicable.

\section{Publisher's Note}

Springer Nature remains neutral with regard to jurisdictional claims in published maps and institutional affiliations.

Received: 14 January 2017 Accepted: 29 October 2018

Published online: 06 November 2018

\section{References}

1. Adesina AA, Ouattara AD. Risk and agricultural systems in northern Cote d'Ivoire. Agric Syst. 2000;66:17-32.

2. Ali M, Abedullah A. Economic and nutritional benefits from enhanced vegetable production and consumption in developing countries. J Crop Prot. 2002;6(1):2002.

3. Antonaci L, Demeke M, Vezzani A. The challenges of managing agricultural price and production risks in sub-Saharan Africa (ESA No 14-09 No. 14-9). Rome: FAO; 2014.

4. Barrett C. Measuring food insecurity. Science. 2010;327:825-8. https://doi. org/10.1126/science.1182768.

5. Birthal PS, Roy D, Negi DS. Assessing the impact of crop diversification on farm poverty in India. World Dev. 2015;72:70-92. https://doi. org/10.1016/j.worlddev.2015.02.015.

6. Bry X. Analyses factorielles simples. (Economica, Ed.) (Economica). Economica; 1995

7. Carletto C, Zezza A, Banerjee R. Towards better measurement of household food security: harmonizing indicators and the role of household surveys. Glob Food Secur. 2013;2(1):30-40. https://doi.org/10.1016/j. gfs.2012.11.006.

8. Cervantes-Godoy D, Dewbre J. Economic importance of agriculture for poverty reduction. OECD Food, Agriculture and Fisheries Working Papers; 2010. http://www.oecd.org/dataoecd/49/19/46341298.pdf. Accessed 15 Dec 2016.

9. Cochran WG. Sampling techniques. 3rd ed. New York: Willey; 1977.

10. Demeke AB, Zeller M. Using panel data to estimate the effect of rainfall shocks on smallholders food security and vulnerability in rural Ethiopia. Hohenheim; 2009.

11. FAO. Measurement and assessment of food deprivation and undernutrition. In: Proceedings of an international scientific symposium. Rome: FAO; 2002.

12. FAO, IFAD, \& WFP. The State of Food Insecurity in the World. Meeting the 2015 International hunger targets: taking stock of uneven progress. ROME; 2015. http://www.fao.org/3/a-i4646e.pdf. Accessed 4 Jan 2017.

13. FAO, WFP. The state of food insecurity in the world: addressing food insecurity in protracted crises. Food and Agriculture Organization of the
United Nations. Rome; 2010. http://www.fao.org/docrep/013/i1683e/ i1683e.pdf.

14. Frayne B, McCordic C. Planning for food secure cities: measuring the influence of infrastructure and income on household food security in Southern African cities. Geoforum. 2015;65:1-11. https://doi.org/10.1016/j. geoforum.2015.06.025.

15. Gecho Y, Ayele G, Lemma T, Alemu D. Livelihood strategies and food security of rural households in Wolaita Zone, Southern Ethiopia. Dev Ctry Stud. 2014;4(14):123-36.

16. Herforth AW. Promotion of traditional african vegetables in kenya and tanzania : a case study of an intervention representing. Cornell University; 2010. file:///Users/amandinesagnieres/Downloads/Herforth.Anna.pdf.

17. Hua W, Hite D. Assessing the relationship between crop choice and land use change using a Markov model. In: Selected paper prepared for presentation at the American agricultural economics association annual meeting, Providence, Rhode Island; 2005.

18. INSAE. Evaluation de la pauvreté au Bénin. Benin: Cotonou; 2013.

19. Jones AD, Shrinivas A, Bezner-kerr R. Farm production diversity is associated with greater household dietary diversity in Malawi: findings from nationally representative data. Food Policy. 2014;46:1-12. https://doi. org/10.1016/j.foodpol.2014.02.001.

20. Joshi PK, Ashok G, Birthal PS, Tewari L. Agriculture diversification in South Asia: patterns, determinants, and policy implications (No. 57), Washington, D.C. 20006; 2003.

21. Magaña-lemus D, Ishdorj A, lii CPR, Lara-álvarez J. Determinants of household food insecurity in Mexico. Agric Food Econ. 2016. https://doi. org/10.1186/s40100-016-0054-9.

22. Mallick D, Rafi M. Are female-headed households more food insecure? Evidence from Bangladesh. World Dev. 2010;38(4):593-605. https://doi. org/10.1016/j.worlddev.2009.11.004.

23. Mandal R, Bezbaruah MP. Diversification of cropping pattern: its determinants and role in flood affected agriculture of assam plains. Indian J Agric Econ. 2013;68(2):169-81.

24. Maxwell D, Caldwell R, Langworthy M. Measuring food insecurity: can an indicator based on localized coping behaviors be used to compare across contexts? Food Policy. 2008;33(6):533-40. https://doi.org/10.1016/j.foodp ol.2008.02.004.

25. Napoli M. Towards a food insecurity multidimensional index (FIMI). Master Thesis, 2011. http://typo3.fao.org/fileadmin/templates/ERP/uni/FIMI.pdf. Accessed 22 Nov 2016.

26. Oyarzun PJ, Mary Borja R, Sherwood S, Parra V. Making sense of agrobiodiversity, diet, and intensification of smallholder family farming in the highland andes of ecuador. Ecol Food Nutr. 2013;52(6):515-41. https:// doi.org/10.1080/03670244.2013.769099.

27. Pellegrini L, Tasciotti L. Crop diversification, dietary diversity and agricultural income: empirical evidence from eight developing countries. Can J Dev Stud. 2014;35(2):211-27.

28. Perz SG. Household demography and land use allocation among small farms in the Brazilian Amazon. Hum Ecol Rev. 2002;9(2):1-16.

29. Ravallion M, Chen S, Sangraula P. New evidence on the urbanization of global poverty (No. WPS4199), Washington; 2008.

30. Riely F, Mock N, Cogill B, Bailey L, Kenefick E. Food security indicators and framework for use in the monitoring and evaluation of food aid programs, Washington, D.C. 20009; 1999

31. Shiyani RL, Pandya HR. Diversification of agriculture in Gujarat: A spacio-temporal analysis. IndianJournal of Agricultural Economics. 1998;53(4):627-39.

32. Stewart WM, Roberts TL. Food security and the role of fertilizer in supporting it. In: 1st international symposium on innovation and technology in the phosphate industry (vol. 46, p. 76-82). Procedia Engineering; 2012. http://doi.org/10.1016/j.proeng.2012.09.448.

33. Swades P, Shyamal K. Implications of the methods of agricultural diversification in reference with Malda district: drawback and rationale. Int J Food Agric Vet Sci. 2012;2(2):97-105. http://www.cibtech.org/jfav.htm

34. Tefera T, Kanampiu F, Groote H De, Hellin J, Mugo S, Kimenju S. The metal silo: an effective grain storage technology for reducing post-harvest insect and pathogen losses in maize while improving smallholder farmers'food security in developing countries. Crop Prot. 2011;30(3):240-5. https://doi.org/10.1016/j.cropro.2010.11.015. 
35. Tekle L, Berhanu K. Determinants of rural farm household food security in Boloso Sore District of Wolaita Zone in Ethiopia. Asian J Agric Ext Econ Sociol. 2015;5(2):57-68. https://doi.org/10.9734/AJAEES/2015/14833.

36. Thierfelder C, Mombeyarara T, Mango N, Rusinamhodzi L. Integration of conservation agriculture in smallholder farming systems of southern Africa: identification of key entry points. Int J Agric Sustain. 2013;11:31730. https://doi.org/10.1080/14735903.2013.764222.

37. Thompson HE, Berrang-ford L, Ford JD. Climate change and food security in Sub-Saharan Africa: a systematic literature review. Sustainability. 2010;2:2719-33. https://doi.org/10.3390/su2082719.

38. Torheim LE, Ouattara F, Diarra MM, Thiam FD, Barikmo I, Hatløy A, Oshaug A. Nutrient adequacy and dietary diversity in rural Mali: association and determinants. Eur J Clin Nutr. 2004;58(4):594-604. https://doi. org/10.1038/sj.ejcn.1601853.

39. Von Braun J. Agricultural commercialization: impacts on income and nutrition and implications for policy. Food Policy. 1995;20(3):1995.
40. Vyas S, Kumaranayake L. Constructing socio-economic status indices: how to use principal components analysis. Health Policy Plan. 2006;21(6):459-68. https://doi.org/10.1093/heapol/czl029.

41. WFP. Analyse Globale de la Vulnérabilité et de la Sécurité Alimentaire (AGVSA). Cotonou: Republique du Benin; 2014.

42. Van Wijk MT. From global economic modelling to household level analyses of food security and sustainability: how big is the gap and can we bridge it? Food Policy. 2014;49:378-88. https://doi.org/10.1016/j.foodp ol.2014.10.003.

43. Zeller M, Sharma M, Henry C. An operational method for assessing the poverty outreach performance of development policies and projects: results of case studies in Africa, Asia, and Latin America. World Dev. 2006;34(3):446-64.
Ready to submit your research? Choose BMC and benefit from:

- fast, convenient online submission

- thorough peer review by experienced researchers in your field

- rapid publication on acceptance

- support for research data, including large and complex data types

- gold Open Access which fosters wider collaboration and increased citations

- maximum visibility for your research: over 100M website views per year

At BMC, research is always in progress.

Learn more biomedcentral.com/submissions 